\title{
Analysis of the referral system to the public endodontics service in a city within the metropolitan area of Belo Horizonte, Minas Gerais, Brazil
}

\author{
Análise do sistema de referência e contrarreferência da \\ Endodontia em um municipio da região metropolitana \\ de Belo Horizonte, Minas Gerais, Brasil
}

\author{
Valéria Maria Barbosa Moreira de MELLO' ${ }^{1}$ [D 0000-0002-1147-3650 \\ Marcos de OLIVEIRA JÚNIOR ${ }^{1}$ iD 0000-0001-9914-5485 \\ Marcos Azeredo Furquim WERNECK ${ }^{1}$ iD 0000-0002-4160-018X \\ Flávio de Freitas MATTOS ${ }^{1}$ iD 0000-0002-6052-2762
}

\section{ABSTRACT}

Objective: Health services evaluation uses both general service monitoring indicators and evaluation research, with the aims of studying service performance and its enhancement through problem solving. This study aimed at analyzing the referral system between primary health care and the secondary level care in endodontics of the Dental Specialties Center in the city of Contagem, Minas Gerais, to seek enhancement of the existing referral protocol. Methods: Secondary data were collected from the municipal data systems as well as from services files, regarding all patients who were attended between 2009 and 2014. Results: Mean time between first appointment and treatment conclusion was 3.12 months. There was higher frequency of individuals from the administrative regions of cities with higher populations and more availability of primary health care units. Similar proportions of single and non-single rooted teeth were treated. High proportions of teeth reached the endodontics service of Dental Specialties Center without possible treatment. Conclusion: Data were generated to provide renovation of the service referral protocol.

Indexing terms: Endodontics. Referral and consultation. Unified Health System.

\section{RESUMO}

Objetivo: A avaliação de serviços utiliza indicadores de monitoramento e pesquisa avaliativa, para estudar o desempenho dos serviços e produzir recomendações que orientem soluções para problemas. Este estudo objetivou analisar a referência e contrarreferência no serviço de Endodontia do Centro de Especialidades Odontológicos do município de Contagem, Minas Gerais e aperfeiçoar o protocolo de encaminhamento. Métodos: Coletaram-se dados secundários dos sistemas de informação municipais e de prontuários dos arquivos

\footnotetext{
v

1 Universidade Federal de Minas Gerais, Departamento de Odontologia Social e Preventiva, Faculdade de Odontologia. Av. Pres. Antônio Carlos, 6627, Pampulha, 31270-901, Sala 3403, Belo Horizonte, MG, Brasil. Correspondência para / Correspondence to: VMBM MELLO. E-mail: <valmoreira2017@hotmail.com>.

$\boldsymbol{\nabla} \boldsymbol{\nabla} \boldsymbol{\nabla} \nabla$

How to cite this article

Mello VMBM, Oliveira Júnior M, Werneck MAF, Mattos FF. Analysis of the referral system to the public endodontics service in a city within the metropolitan area of Belo Horizonte, Minas Gerais, Brazil. RGO, Rev Gaúch Odontol. 2019;67:e20190021. http://dx.doi.org/10.1590/1981-8 6372019000213434
} 
do Centro de Especialidades Odontológicos em estudo, relativos ao universo dos pacientes atendidos entre 2009 e 2014. Resultados: O tempo médio para conclusão do tratamento foi de 3,12 meses. Houve maior frequência de pacientes oriundos das regiões municipais onde há maior população e maior número de unidades básicas de saúde. Houve números semelhantes entre dentes uni radiculares e mutlirradiculares atendidos. Grande proporção de dentes chegou à endodontia do Centro de Especialidades Odontológicos sem possibilidade de tratamento. Conclusão: Geraram-se dados para subsidiar a renovação do protocolo de funcionamento do serviço.

Termos de Indexação: Endodontia. Encaminhamento e consulta. Sistema Único de Saúde.

\section{INTRODUCTION}

For many years, dental care in Brazil was characterized by attending restricted population groups, by means of programs with a curativist approach, with the result that there was a low level of coverage from both the assistential and population aspects. The remainder of the population was excluded and dependent on merely curative and mutilating services [1].

The use of services, in turn, could also be influenced by accessibility, understood as being related to the obstacles imposed by the services and the power of the users for overcoming these difficulties [2]. Among factors of the service associated with greater use are: adequate offer of procedures according to the population's needs; geographical and organizational accessibility; in addition to definition of a heal service professional to follow-up each case, especially for specialized procedures [3].

The application of evaluation in health for the area of oral health, reordering of policies, programs and services is a constant challenge for monitoring the services to improve quality and oral health surveillance. Evaluations of services in secondary oral health care, particularly in Brazil, are at an incipient stage of construction of evidence, above all with the implementation of the CEOs. The practice of evaluation in health services must be understood from two perspectives. On the one hand, the most common type of evaluation of service uses general indicators for monitoring the service and system, and these are used in punctual situations, seeking to generate actions that guarantee improvement in quality of life. On the other hand, we could resort to evaluation research that results in academic effort, with the purpose of studying the performance of the services, and producing recommendations that guide solutions to the problems identified [4].

According to Faulkner [5], coordination between Primary and Secondary Care must be understood as being common action or effort. Some authors have also denominated it as interface; it received attention in the recent reforms of the European health systems as initiatives to strengthen Primary Health Care. In these countries, the possible forms of interface with secondary care, in addition to the traditional referral for the execution of procedures, range from the common definition of case management protocols through to the development of attendance programs shared among specialties and professionals of the primary network.

Since toothache is a great reason for seeking dental care, this justifies the high demand for endodontic services. In this treatment, various sessions are required for opening the tooth up to the pulp tissue, and recovery of the lesioned tissues. Or, the replacement of dressings until the tooth is healthy for closure of the canals, and later restoration, thus restoring the function of the tooth. In general, this treatment is high cost in private dental offices, and frequently is not offered by the public service. This is why there is a high demand, causing a waiting list [6].

Contagem is one of the 34 municipalities in the metropolitan region of Belo Horizonte. It is situated in the central region of the state of Minas Gerais. It has a population of close to 647,000 inhabitants [7]. In the municipality, there is a Dental Specialties Center ("Centro de Especialidades Odontologicos - CEO") of type II that was implemented in 2008. This center is responsible for attending to the population of seven administrative districts into which the municipality is divided: Sede, Eldorado, Petrolândia, Vargem das Flores, Industrial (which incorporates the region of Riacho), Ressaca and Nacional. The center attends to the following specialties: stomatology, periodontology, minor oral surgery, endodontics, dental prostheses (total removable prostheses, esthetic partially removable prostheses), pediatric dentistry and care of patients with special needs (PNE). Up to now, seven years after its implementation, no evaluation has been made with regard to the accessibility to or use of the CEO of Contagem.

The aim of this study was to analyze the process of referral and counter-referral between Primary Care and Secondary Care in the service of Endodontics in the municipality of Contagem, Minas Gerais, and subsidize the 
enhancement of the protocol of referral to the endodontic service of the municipality by means of analyzing the effectiveness of the endodontic service of the municipality.

\section{METHODS}

This was a descriptive, quantitative study of an evaluative nature, for analyzing the coverage and resolutivity of the referrals and counter-referrals made to the endodontic service of the Dental Specialties Center of the municipality of Contagem, Minas Gerais.

Secondary data were used, collected from the municipal information systems and from the record charts contained in the files of the CEO under study. The period covered was from 2009 to 2014, For access to these sources, a Letter of Agreement was obtained from the Secretary for Health of the municipality of Contagem and approval from the Research Research Ethics Committee of UFMG protocol CAAE No.48123815.8.0000.5149.

From the above-mentioned secondary sources of information, data were collected about the following variables: number of patients who were referred to the CEO; their sex and age-range; type of tooth referred for treatment; number of teeth referred to endodontics, which were extracted; interval between beginning and conclusion of attendance of patients treated by endodontics; number of patients who abandoned endodontic treatment and restorative status of the teeth that arrived for endodontic treatment. All the variables were analyzed from the perspective of the totality of the municipality and the particularity of each of its administrative regions. Descriptive data analysis was performed as well as comparative analyses by means of the Exact Fisher Test, using the program Stata - Statistical Data Analyses, version 14.0.

\section{RESULTS}

Data relative to a universe of the 507 patients who had access to the CEO were obtained, and who were referred to the Endodontic service, between the years 2009 and 2014. The information relative to patients who had incomplete data, due to error in the system and lost or incomplete clinical record charts were excluded from the analyses. No statistically significant differences were found.

The absolute and relative numbers pertinent to access of patients to the CEO of Contagem may be visualized in table 1. Higher relative frequency was perceived of the individuals coming from Eldorado (25.8\%), closely followed by those from Industrial (22.3\%). In conjunction, the two districts totaled almost half of the use of the service. Curiously, the lowest percentage of individuals attended by the service came from Sede, district where the CEO under study was localized. In the total municipality, the female sex predominated.

Table 1. Population distribution, regionalized and by gender of patients who had access to endodontic treatment at the Center of Dental Specialities of Contagem.

\begin{tabular}{|c|c|c|c|c|c|c|}
\hline \multirow{3}{*}{ District } & \multicolumn{4}{|c|}{ Sex } & \multirow{2}{*}{\multicolumn{2}{|c|}{ Total }} \\
\hline & \multicolumn{2}{|c|}{ Female } & \multicolumn{2}{|c|}{ Male } & & \\
\hline & $\mathrm{n}$ & $\%$ & $n$ & $\%$ & $\mathrm{n}$ & $\%$ \\
\hline Eldorado & 93 & 25.8 & 41 & 28.4 & 134 & 26.6 \\
\hline Industrial & 81 & 22.3 & 37 & 25.0 & 118 & 23.0 \\
\hline Nacional & 37 & 10.2 & 08 & 5.4 & 45 & 8.8 \\
\hline Petrolândia & 51 & 14.0 & 18 & 12.8 & 69 & 13.7 \\
\hline Ressaca & 38 & 10.7 & 11 & 7.4 & 49 & 9.8 \\
\hline Sede & 18 & 4.9 & 09 & 6.1 & 27 & 5.3 \\
\hline V das Flores & 44 & 12.1 & 21 & 14.9 & 65 & 12.9 \\
\hline Total & 362 & 71.7 & 145 & 28.3 & 507 & 100 \\
\hline
\end{tabular}

The relative numbers, regionalized, per age-range and per sex of individuals showed that after the first consultation individuals did not continue with treatment, thus characterizing abandonment of treatment. In all the municipal regions there was high relative frequency of abandonment, with the patients coming from the Nacional (68.9\%) and Sede $(77.77 \%)$ districts presenting the lowest rates of desistance from endodontic treatment. There was high rate of abandonment of treatment, disseminated among all the age-ranges analyzed, with frequency a little lower among individuals of 13 to 18 years of age (77.77\%). Abandonment of treatment was also higher among women (80.88\%) than among men (77.39) (tables 2 and 3).

Relative to the demand stratified according to the types of teeth that arrived at the endodontic services of the CEO ( $n=521)$, the numbers were similar when the single rooted (259) and mutli-rooted (262) teeth were compared. 
Table 2. Abandonment of endodontic treatment, comparison, by region.

\begin{tabular}{|c|c|c|c|c|c|}
\hline \multirow{2}{*}{ District } & \multicolumn{3}{|c|}{ Abandonment of treatment (\%) } & \multirow[t]{2}{*}{ Total } & \multirow[t]{2}{*}{$p$-value* } \\
\hline & Yes & & No & & \\
\hline Eldorado & $110(81.48)$ & 25 & $(18.52)$ & $135(100)$ & 0.371 \\
\hline Industrial & $99(85.34)$ & 17 & $(14.66)$ & $116(100)$ & \\
\hline Nacional & $31(68.90)$ & 14 & $(31.10)$ & $45(100)$ & \\
\hline Petrolândia & $56(81.15)$ & 13 & $(18.85)$ & $69(100)$ & \\
\hline Ressaca & $41(83.67)$ & 08 & $(16.33)$ & $49(100)$ & \\
\hline Sede & $21(77.77)$ & 06 & $(22.23)$ & $27(100)$ & \\
\hline V das Flores & $55(83.33)$ & 11 & $(16.67)$ & $66(100)$ & \\
\hline Total & 413 & & 94 & 507 & \\
\hline
\end{tabular}

Note: *Exact Fisher Test.

Table 3. General Profile endodontic treatment abandonment, by age range and sex.

\begin{tabular}{lcccc}
\hline \multirow{2}{*}{ Age (years) } & \multicolumn{2}{c}{ Abandonment of treatment $\%$ Total } & p-value* \\
\cline { 2 - 3 } & Yes & No & & \\
\hline 6 to 12 & $30(81.08)$ & $07(18.92)$ & $37(100)$ & 0.836 \\
13 to 18 & $56(77.77)$ & $16(22.23)$ & $72(100)$ & \\
19 to 30 & $63(81.81)$ & $14(18.19)$ & $77(100)$ & \\
31 to 59 & $229(80.91)$ & $54(19.09)$ & $283(100)$ & \\
60 and over & $32(84.21)$ & $06(15.79)$ & $38(100)$ & \\
\hline Total & 410 & 97 & 507 & \\
\hline Sex & & & & \\
\hline Female & $292(80.88)$ & $69(19.12)$ & $361(100)$ & 0.617 \\
Male & $113(77.39)$ & $33(22.61)$ & $146(100)$ & \\
\hline Total & 405 & 102 & 507 & \\
\hline
\end{tabular}

Note: *Exact Fisher Test.

It was not possible to analyze the mean time interval between referral of patients to the endodontic services of CEO, and performing the first consultation, due to the failures in the records. However, when analyzing the mean time elapsed between the first consultation at the endodontic services of the CEO and conclusion of treatment, a mean interval of 3.12 month for each patient was found. Those coming from the districts Ressaca (3.58 months), Eldorado (3.54 months) and Vargem das Flores (3.27 months) were above this mean interval. Below this mean time interval were the districts Industrial (3.02 months), Nacional (2.97 months), Petrolândia (2.47 months) and Sede (2.32 months) (table 4).

Analysis of the frequency of tooth losses before the possibility of starting with endodontic treatment, in
Table 4. Mean number of months of treatment in endodontics of the CEO, general and by region.

\begin{tabular}{lcc}
\hline District & Mean & Standard deviation \\
\hline Eldorado & 3.54 & 0.30 \\
Industrial & 3.02 & 0.29 \\
Nacional & 2.97 & 0.55 \\
Petrolândia & 2.47 & 0.36 \\
Ressaca & 3.58 & 0.88 \\
Sede & 2.32 & 0.69 \\
V das Flores & 3.27 & 0.42 \\
\hline Total & 3.12 & 3.37 \\
\hline
\end{tabular}

decreasing order occurred among individuals of 60 years or older $(72.7 \%), 6$ to 12 years $(58.3 \%), 13$ to 18 years $(52.6 \%)$ and 19 to 59 years (28.57\%). Extraction was the only treatment possible for $39.7 \%$ of uniradicular teeth and for $39.7 \%$ of the multi-rooted teeth referred for endodontic treatment. Taking the administrative regions as a basis, the district Industrial presented the highest proportion of extracted teeth (34.6\%), followed by Eldorado (19.2\%), and Petrolândia (15.4\%). The0 districts Nacional, Ressaca, Sede and Vargem das Flores showed equal proportions in this indicator $(7.7 \%)$.

Failures in the records prevented verification of the presence or absence of temporary restorations in all the teeth that arrived at the CEO Contagem for endodontic treatment. Patients referred to the endodontic service were expected to arrive at secondary care with all their teeth

Table 5. Regionalized, comparative profile of status of tooth referred when patient arrived at endodontic service of CEO.

\begin{tabular}{lcccc}
\hline \multirow{2}{*}{ District } & \multicolumn{2}{c}{ Suitability of medium (\%) } & \multirow{2}{*}{ Total } & p-value* \\
\cline { 2 - 3 } & Yes & No & & \\
\hline Eldorado & $71(79.77)$ & $18(20.23)$ & $89(100)$ & 0.724 \\
Industrial & $50(71.42)$ & $20(28.58)$ & $70(100)$ & \\
Nacional & $23(85.18)$ & $04(14.82)$ & $27(100)$ & \\
Petrolândia & $32(78.05)$ & $09(21.95)$ & $41(100)$ & \\
Ressaca & $17(70.83)$ & $07(29.17)$ & $24(100)$ & \\
Sede & $09(69.23)$ & $04(30.77)$ & $13(100)$ & \\
V das Flores & $22(73.33)$ & $08(26.67)$ & $30(100)$ & \\
\hline Total & 224 & 70 & 294 \\
\hline
\end{tabular}

Note: *Exact Fisher Test. 
temporarily restored by primary care. This affirmative was not true among $21.3 \%$ of the women and $28.8 \%$ of the men. The regional distribution of absence of temporary restoration may be visualized in table 5 . In the different age groups studied, the same failure was detected in $41.6 \%$ of the teeth of patients between 6 and 12 years; $35 \%$ between 13 and 18 years; $20.1 \%$ of 60 years or older and $11.62 \%$ between 19 and 39 years.

\section{DISCUSSION}

This study began with the presupposition presented by Goes et al. [4]. According to the authors, the practice of evaluation in health services must be understood from two perspectives: the most common type uses general indicators of monitoring the service and system, and is used in punctual situations, seeking to generate actions that guarantee improvement in quality. On the other hand, we could resort to evaluation research that results in academic effort, with the purpose of studying the performance of the services, and producing recommendations that guide solutions to the problems identified.

The CEO must have microregional coverage with a population base according to epidemiological and population criteria. Type II would have the capacity to attend a referred population of 130,000 inhabitants $[8,9]$. As yet, there are no precise data with reference to the population contingent of the municipality that depends on SUS for oral health care at secondary level, the population of Contagem of 637,960 inhabitants is well above the recommended number.

The use of services made available could be influenced by accessibility to the services, understood as being related to the obstacles imposed by the services and the power of the users for overcoming these difficulties [2]. Among the factors of the service associated with greater utilization are: adequate offer of procedures according to the population's needs and geographical and organizational accessibility. In Contagem the territorial area is 194,586 $\mathrm{Km}$ [2], divided into seven administrative regions. Higher relative frequency was perceived of the individuals coming from Eldorado (25.8\%), closely followed by those from Industrial (22.3\%), showing a joint total of almost half of those who used the service. This could be explained by the localization of 14 of the 31 municipal primary health units, and 32 of the 44 dentists in these regions. The lowest percentage of individuals attended by the services came from Sede, the district where the CEO under study is localized, which has only 2 primary health units with 7 dentists.

At municipal level, there was predominance of the female sex among the population attended by the CEO with percentage differences among the administrative regions. In Brazil, women make more use of the health services than men and tend to evaluate their health in a more negative manner [10]. Further studies need to be conducted to identify the possible demographic differences or of any other nature that would explain this variation in Contagem.

A large part of abandonment of endodontic treatment $(71.1 \%)$ occurred among adult individuals. In spite of not having been the aim of this study, it could be supposed that the numbers are reflections of the involvement of the age range from 19 to 59 years in the work market, which makes it difficult to ensure continuity of treatment.

The municipal protocol in force about referral of patients to the endodontic service of the CEO does not establish quantitative or proportional goals for the treatment of uni- or multi-radicular teeth [7]. This was reflected in the findings of this study with regard to the type of tooth that arrived at the endodontic service of the CEO. According to them, in the entire municipality, of the 521 teeth $(100 \%)$, there were very similar numbers when the uni-radicular (259) and multi-radicular (262) teeth were compared.

There were failures in the records of the CEO which prevented verification of the mean time interval between referral of patients to the endodontic services of the CEO and realizing the first consultation, a problem that needs to be corrected. Although this was not the only variable involved, this waiting time certainly has an influence on the finding of this study that $39.7 \%$ of the teeth referred for endodontic treatment effectively had to be extracted. Nationally, in SUS, among the specialized dental services of the CEO, endodontics is the one most frequently offered and requested, totaling $68.4 \%$ of all the referrals made by oral health teams [11].

In addition it is necessary to verify how many patients referred to endodontic services of the CEO Contagem do not show up for the first appointment made for consultation. In Belo Horizonte, whose metropolitan 
region belongs to Contagem, young adults of the male sex from certain districts, referred to the surgery and endodontic specialties, and who remained on the waiting list for a longer time, showed a higher frequency of not showing up for appointments.

The interface between primary and secondary health care must be extended beyond the traditional type of referral for having procedures performed. It needs to cover a range starting with the common definition of case management protocols, through to the development of attendance programs shared among specialties and professionals of the primary network [5]. Among the different districts, relative homogeneity was verified, without statistically significant differences in the mean time elapsed between the first endodontic consultation with the CEO and conclusion of treatment, in a mean time interval of 3.12 months for each patient, close to the Brazilian mean time, in which the waiting time for endodontic treatment at the CEO exceeds 90 days [10]. This value reveals an undesirable situation, far beyond that of the proposed production of a type II CEO. This process is not always finalized, due to socioeconomic and cultural questions, and also the low offer of prosthesis laboratories that serve the public sector.

In addition to the presence of failures in the records, there possibly are other causes in the fields of understanding the model of care, management of the work process, setting up of the procedures and implication of professionals with the organization of actions in the CEO. In further more detailed studies it will be necessary to think of what can be done to understand this situation better and subsidize the management processes.

On approaching the qualification of specialized oral health care, some challenges have been posed, among which two deserve to be pointed out, especially the PMAQ-CEO which intend to cope with: the low level of integration of the CEO professionals with the oral health teams of primary care and with the other points of the oral health care network; and the absence of protocols for the referral and counter-referral of users, which generate an excessive number of inadequate referrals [9].

Although there is a protocol in force in Contagem, this does not prioritize groups of teeth or age-ranges. This led to the finding that there was a large proportion of users who arrived at the CEO with their teeth already in a condition that made them impossible to treat, both among uni- and multi-radicular teeth, in all age groups, and with emphasis on patients of 60 years of age and older. Among the different regions, the impossibility of performing restorative treatment was outstandingly more frequent among patients coming from the district Industrial, which has made it necessary to go more deeply into understanding the causes of this fact.

Secondary care in the municipality of Contagem follows a system of referral and counter-referral elaborated at the time when the CEO was inaugurated. This system establishes that referred users must present with removal of all the carious tissue from the tooth to be treated, adequate opening of the pulp chamber, delayed dressing, and adequate provisional coronal sealing. It is the primary care oral health team's responsibility to follow-up the clinical state of the user who has been referred to the CEO in cases in which the waiting time for making an appointment for the first consultation is longer than 4 (four) months. Appointments for these users must initially be made with the TSB for maintenance, and if necessary, with the dentist afterwards [7]. At the time of the first appointment for endodontic consultation at the CEO, no presence of a temporary restorative treatment was verified in proportions close to $30 \%$ of users among the different municipal districts. These numbers rose to $41.6 \%$ among patients in the age-range from 6 to 12 years.

In the municipality of Contagem, the work of endodontists at the CEO is based in the mechanical and manual instrument techniques, due to their low cost, in spite of the number of clinical sessions involved. Today, however, nickel titanium (NiTi) rotary instruments are known to be facilitators, because their use has shown a favorable cost/benefit ratio. They make it possible to clean the canals in a shorter period of time, and with greater clinical efficiency, in addition to allowing treatment to be less tiring for both patients and professionals, who consequently are capable of attending a larger number of patients in a shorter period of time, thereby contributing to improvement in access to services and diminishing the time spent waiting in line for treatment $[12,13]$.

In this study information was collected that made it possible to analyze the process of referral and counterreferral between Primary Care and Secondary care in the Endodontic service in the municipality of Contagem, Minas Gerais. The effectiveness of its action, from the perspective of availability of the service to the different regions of the municipality, the fulfillment of the existent protocol of work 
and the effective performance and conclusion of treatment of the referred patients was evaluated.

It is possible that the protocol that rules the flows of referral and counter-referral between primary care and specialized care is not being correctly observed, or that there possibly is an excessive length of time elapsed between referral and the first consultation at the CEO.

Data were generated that may be able to subsidize renewal of the protocol of work in force for the studied service. This renewal must be aware of the pressing needs, which are: effective monitoring of the correct indication of endodontic treatment for each tooth, when patients are being referred to the CEO; effective control of performing prior temporary restorations in the teeth that are referred for endodontic treatment; effective monitoring of the waiting time for endodontic treatment, and reduction in the mean time interval between the first consultation at the CEO and conclusion of endodontic treatment. The authors hope that the proposal for monitoring and evaluation here presented becomes a permanent feature of work in the studied municipality and may encourage the development of proposals relative to the other specialties present in the CEOs, not only in this municipality, but in others as well.

\section{Collaborators}

VMBM MELLO contributed to study design, data collection, data analysis and paper writing. M OLIVEIRA JÚNIOR, contributed to paper writing. MAF WERNECK and FF MATTOS contributed to study design, data analysis and paper writing.

\section{REFERENCES}

1. Oliveira RS, Magalhães BG, Gaspar GS, Rocha ACP, Góes PSA. Avaliação do grau de satisfação dos usuários nos serviços de saúde bucal da estratégia de saúde da família. Rev Bras Pesqui Saúde. 2009;11(4):34-8.

2. Chaves $\mathrm{SCl}$, Barros SG, Cruz DN, Figueiredo $\mathrm{ACL}$, Moura BLA, Cangussu MCT. Política nacional de saúde bucal: fatores relacionados com a integralidade do cuidado. Rev Saúde Públ. 2010;44(6):1005-1013. http://dx.doi.org/10.1590/S0034-89 102010005000041
3. Giovanella L, Lobato LVC, Carvalho Al, Conill EM, Cunha EM. Sistemas municipais de saúde e a diretriz da integralidade da atenção: critérios para avaliação. Saúde Debate. 2002;26:37-61.

4. Goes PSA, Figueiredo N, Neves JCS, Silveira FMM, Costa JFR, Pucca Júnior GA, et al. Avaliação da atenção secundária em saúde bucal: uma investigação nos centros de especialidades do Brasil. Cad Saúde Pública. 2012;28(Suppl):S81-89. http:// dx.doi.org/10.1590/S0102-311X2012001300009

5. Faulkner A, Mills N, Bainton D, Baxter K, Kinnersley P, Peters $T$, et al. A systematic rewiew of the effect of primary care based service innovations on quality and patterns of referral to specialist secondary care. Br J Gen Pract. 2003;53(496):872-84.

6. Oliveira JLC, Saliba NA. Atenção odontológica no Programa Saúde da Família de Campos dos Goytacazes. Ciênc Saúde Coletiva. 2005;10(Suppl):297-302. http://dx.doi.org/10.1590/ S1413-81232005000500030

7. Prefeitura de Contagem. Diretrizes para a organização da saúde bucal do município de Contagem. Contagem: Secretaria Municipal de Saúde; 2012.

8. Lino PA, Werneck MAF, Lucas SD, Abreu MHNG. Análise da atenção secundária em saúde bucal no Estado de Minas Gerais, Brasil. Cien Saude Colet. 2014;19(9):3879-88. http:// dx.doi.org/10.1590/1413-81232014199.12192013

9. Brasil. Ministério da Saúde. Programa nacional de melhoria de acesso e de qualidade da atenção básica (PMAQ): manual instrutivo. Brasília: Ministério da Saúde; 2012 [citado 2017 Out 15]. Disponível em: <http://189.28.128.100/dab/docs/ publicacoes/geral/manual_instrutivo_pmaq_site.pdf>.

10. Travassos C, Viacava F, Pinheiro R, Brito A. Utilização dos serviços de saúde no Brasil: gênero, características familiares e condição social. Rev Panam Salud Publica 2002;11(5/6):365-73.

11. Martins RC, Reis C, Matta-Machado T, Amaral JHL, Werneck MAF, Abreu M. Relationship between Primary and Secondary Dental Care in Public Health Services in Brazil. PLoS One. 2016;11(10):e0164986. http://dx.doi.org/10.1371/journal.pone. 0164986

12. Machado AT, Werneck MAF, Lucas SD, Abreu MHNG. Who did not appear? First dental visit absences in secondary care in a major Brazilian city: a cross-sectional study. Ciên Saúde Coletiva. 2015;20(1):289-98. http://dx.doi.org/10.1590/14 13-81232014201.01012014

13. Seijo MOS. O ensino de endodontia em uma instituição pública: percepção dos estudantes [dissertação]. Belo Horizonte: Universidade Federal de Minas Gerais; 2010.

Received on: 24/5/2018 Final version resubmitted on: 30/10/2018 Approved on: 5/12/2018 